\title{
Smell disorders associated with COVID-19 infection
}

\author{
Mohammad Waheed El-Anwar, Sherif Mamdoh Mohamed and Ahmed Hassan Sweed ${ }^{*}$ (D)
}

\begin{abstract}
Background: We performed a search in the PubMed databases, Web of Science, LILACS, MEDLINE, SciELO, and Cochrane Library using the keywords COVID-19, Novel coronavirus, corona, 2019-nCoV, SARS-CoV-2, ENT, nose, anosmia, hyposmia, smell, olfactory, ORL, different ENT related symptoms. We reviewed published and peerreviewed studies that reported the ENT manifestations in COVID-19 laboratory-confirmed positive patients.

Main text: Within the included 2549 COVID-19 laboratory-confirmed positive patients, smell affection was reported in 1453 patients (57\%). The other reported ENT manifestations were taste disorder (49.2\%), headache (42.8\%), nasal blockage (26.3\%), sore throat (25.7\%), runny nose or rhinorrhea (21.3\%), upper respiratory tract infection (URTI) (7.9\%), and frequent sneezing (3.6\%).

Conclusion: Smell affection in COVID-19 is common and could be one of the red flag signs in COVID-19 infection. With a sensitivity of utilized questionnaire in smell identification, a homogenous universal well-defined COVID-19 questionnaire is needed to make the COVID-19 data collection more sensible.
\end{abstract}

Keywords: COVID-19, Coronavirus, Anosmia, Hyposmia, Smell, Olfactory, ENT, Otorhinolaryngology

\section{Background}

At December 2019, the severe acute respiratory syndrome coronavirus 2 (SARS-CoV-2), initially known as the 2019 novel coronavirus (2019-nCoV), started in China in Wuhan $[1,2]$. Since that moment, this novel virus, also named as coronavirus disease 2019 (COVID19), has crossed all countries' borders with dramatic spread all over the world till the World Health Organization (WHO) defined it as a pandemic disease on March 11, 2020.

The COVID-19 is part of the species of the SARSrelated coronaviruses that over the last two decades have led to preceding epidemics as SARS-CoV in China in 2002-2003 [3] and the Middle East Respiratory Syndrome (MERS-CoV) in Saudi Arabia in 2012-2013 [4].

The novel COVID-19 is presented mainly by lower respiratory tract-related manifestations such as fever, cough, dyspnea, and chest tightness that could progress

\footnotetext{
* Correspondence: dr.orl.sweed@gmail.com

Otorhinolaryngology, Head and Neck Surgery Department, Faculty of Medicine, Zagazig University, Zagazig, Egypt
}

quickly to acute respiratory distress syndrome (ARDS) [5]. However, COVID-19 leads as well to different upper respiratory tract-related manifestations comprising sore throat, smell dysfunction, and nasal congestion [6].

The available data on the ear nose throat (ENT) manifestations of COVID-19 is recently published [7] and review studies on smell in COVID-19-positive patients are still growing.

Smell and taste dysfunctions in COVID-19 patients were sparsely cited in the literature and there is still a paucity of peer-reviewed publications to support a causal association between COVID-19 and anosmia [7, 8].

Thus, the aim of the current work was to detect and discuss the smell disorders associated with confirmed COVID-19 infection in the reviewed and published literature.

\section{Main text \\ Methods \\ We searched several medical databases, including PubMed databases, Web of Science, LILACS, MEDL}


INE, SciELO, and Cochrane Library at July 2020 to find out relevant articles. We used the following keywords: COVID19, COVID-19, Novel Coronavirus, corona, 2019-nCoV, SARS-CoV-2, anosmia, hyposmia, smell, olfactory, smell dysfunction, nose, and different ENT related symptoms.

We focused our review on studies reporting the smell disorders in laboratory-confirmed positive COVID-19 patients. We included studies that asked about and demonstrated the incidence smell disorders among other COVID-19 manifestations such as fever, cough, and shortness of breathing in laboratoryconfirmed positive COVID-19 patients. Non-published studies, studies that were not published in indexed journals or published without peer review, studies that included suspected cases beside confirmed cases, studies that did not ask about or test for smell disorders, and studies that are not available in English language were excluded from the current review. Then the authors collected, tabulated, and analyzed the results of the studies that met these inclusion and exclusion criteria.

\section{Results}

Between a large number of read COVID-19 papers, 23 reviewed and published studies met the inclusion and exclusion criteria of the present review and reported smell disorders in COVID-19-positive patients [9-31] (Table 1). These studies included 2549 laboratoryconfirmed positive COVID-19 patients, 1107 females (43.4\%) and 838 males (32.8\%). While in 603 included patients, the gender was not mentioned and one patient was gender diverse. Smell disorder was detected in 1453 patients (57\%). In 648 patients of them, type of smell disorders was defined as anosmia in 376 patients (58\%), hyposmia in 270 patients (41.6\%), dysosmia in 2 patients $(0.4 \%)$.

Smell affection was early (first presentation/only presentation) in 337 patients (28.3\%) and was late (3 to 5 days after the initial symptoms of the acute respiratory tract infection) in 807 patients (71.7\%) (Fig. 1). Only $0.9 \%$ of cases with early smell disorder suffered from severe to critical COVID-19 sequelae; on the other hand, $4.23 \%$ of cases with late smell dysfunction got the worst form of COVID-19 disease.

Early (complete) recovery of smell (within 2 weeks) was reported in 556 patients $(60.5 \%)$, while late (partial) recovery was detected in 121 patients (13.2\%). On the other hand, in 242 patients (26.3\%), smell did not recover (Fig. 1).

Olfactory evaluation was performed by questionnaire in most patients (1281 patients, $88.2 \%$ ), while smell test was used in 172 patients (11.8\%). The utilized smell identification tests were University Of Pennsylvania
Smell Identification Test (UPSIT), Connecticut Chemosensory Clinical Research Center orthonasal olfaction test (CCCRC) and Le Nez du Vin "six suprathreshold odors forced multiple choice smell identification test." There is discrepancy in smell identification results between history-questionnaire evaluation and other tests. Among those 172 COVID-19 patients evaluated by smell identification tests, 160 patients proved to have smell disorder; either anosmia or variable degree of hyposmia according to the scale in the aforementioned smell identification tests, and only 105 patients had smell disorder as main complaint. So, sensitivity of questionnaire in smell identification $(105 / 160=65.6 \%)$.

When we reviewed the smell affection in relation to the severity of COVID-19 disease, we found that 921 smell-affected patients $(96.23 \%)$ were asymptomatic or had mild to moderate COVID-19 condition "No hospitalization-No oxygen therapy," 29 smell-affected patients (3.02\%) had severe COVID-19 disease, and 7 smell-affected patients were critical COVID-19 (0.73\%).

In 1515 included patients, complete ENT symptomatology was recorded in which smell disorder was detected in 843 patients (55.6\%), and taste disorder was detected in 746 patients (49.2\%). Meanwhile, other ENT manifestations were runny nose or rhinorrhea reported in 323 patients $(21.3 \%)$, nasal congestion and blockage manifested in 398 patients (26.3\%), sore throat reported in 420 patients $(25.7 \%)$, headache presented in 648 patients $(42.8 \%)$, sneezing in 54 patients $(3.6 \%)$, and URTI reported in 119 patients (7.9\%) (Fig. 2), while non-ENT manifestations in those patients were fever in 869 patients (57.4\%), cough in 1058 patients (69.8\%), dyspnea in 336 patients $(22.2 \%)$, arthralgia/myalgia in 674 patients (44.5\%), asthenia/fatigue in 556 patients (36.7\%), and loss of appetite in 414 (27.3\%) (Fig. 3).

\section{Discussion}

A novel coronavirus (CoV) epidemic, produced by the severe acute respiratory syndrome coronavirus-2 (SARS-CoV-2), began in December 2019 from China $[4,7]$. On February 11, 2020, the WHO named the disease caused by this novel virus as COVID-19. The widespread transmission and infectivity of COVID-19 marks it as a significant pathogen with a considerable health threat [32].

COVID-19 manifests with a wide clinical range extending from no symptoms to multi-organ dysfunctions and septic shock. Despite its rapid distribution worldwide, the clinical features of COVID-19 remain to a variable extent non-specific [6-8, 32].

The nasal, nasopharyngeal, and/or the orpharyngeal tissues are part of the main harbor locations of the infection, main site of sample taking for testing, and a main 


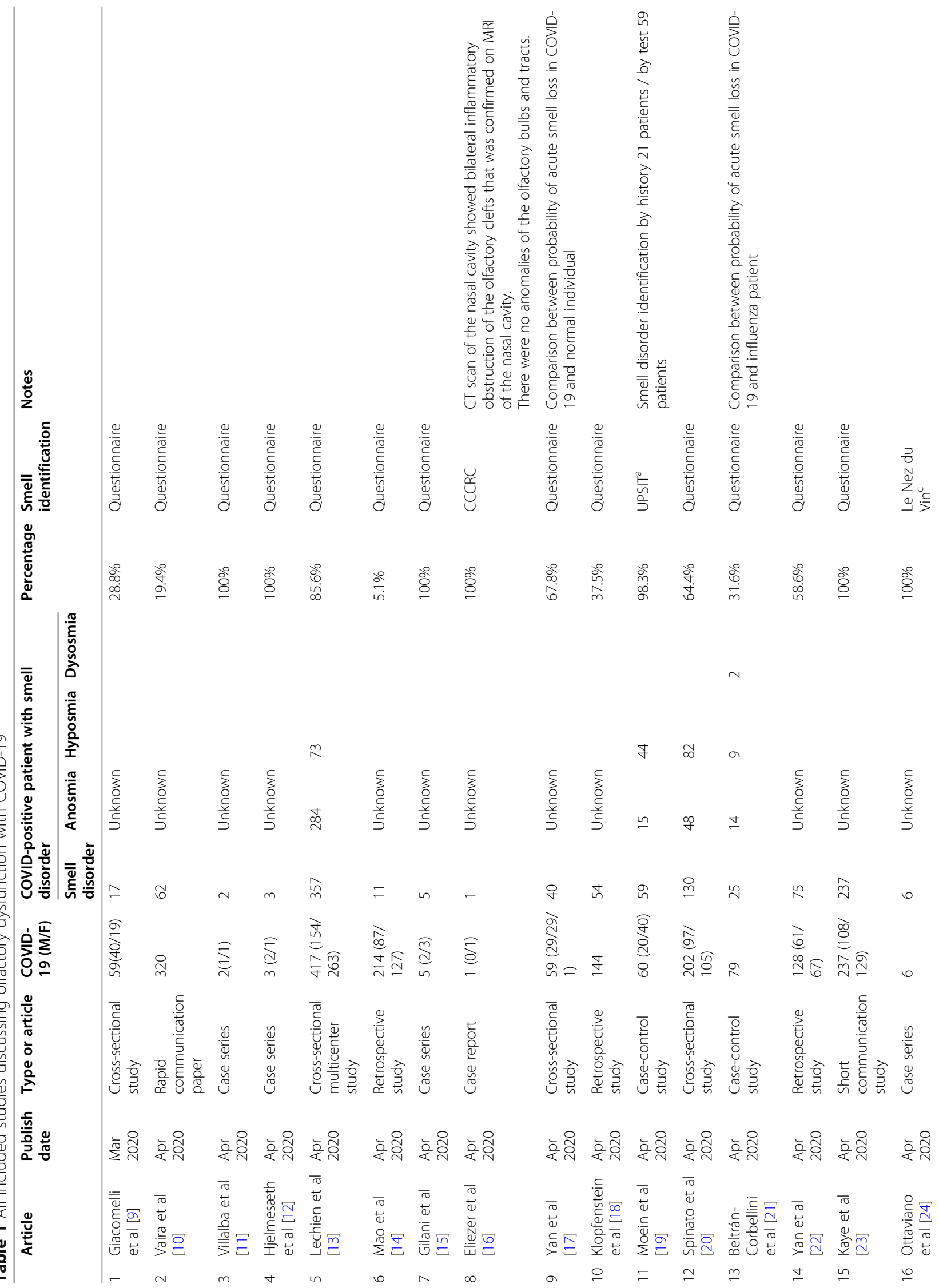




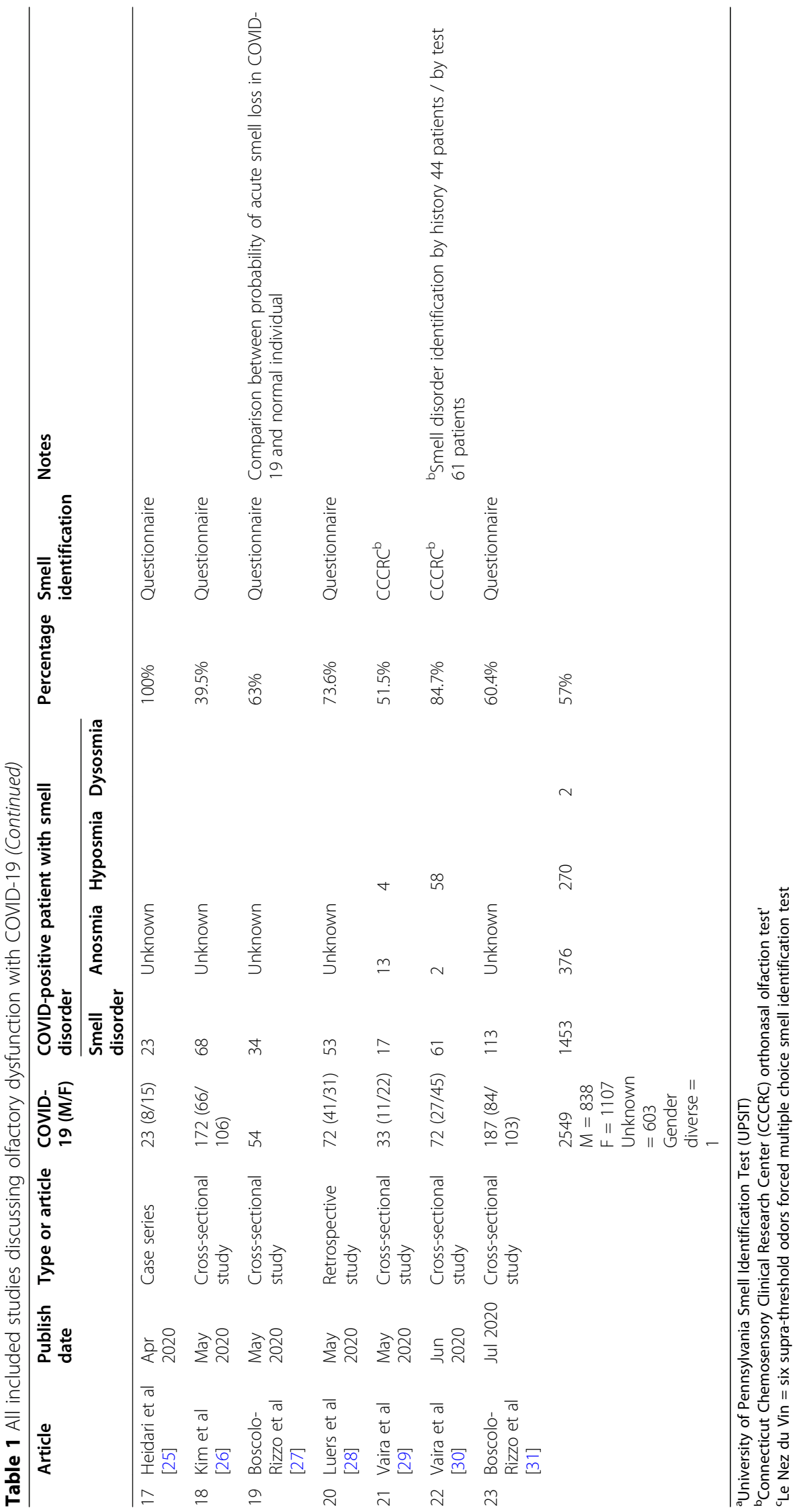



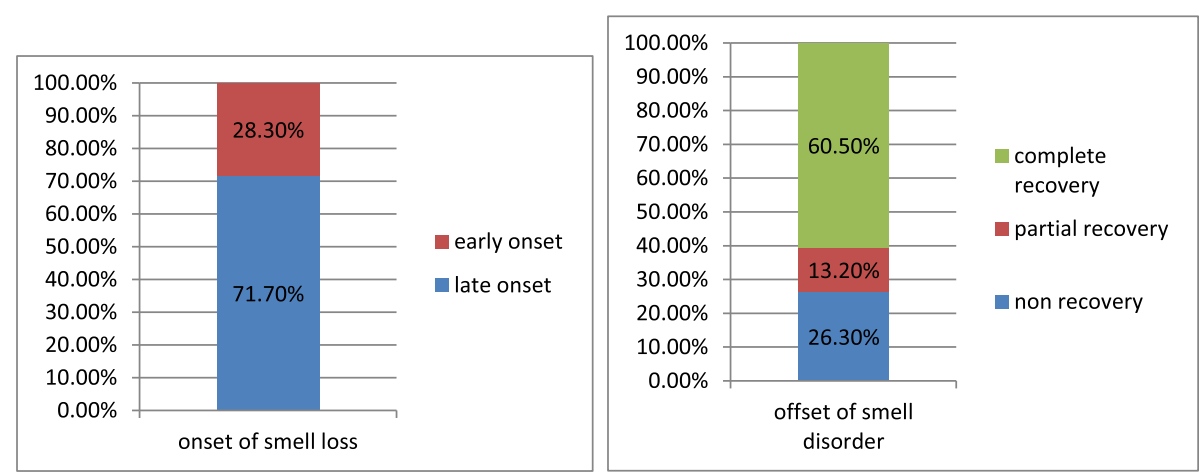

Fig. 1 Onset/offset of smell disorder with COVID-19 patients; onset (early-late)-offset (complete recovery-partial recovery-persistent smell disorder)

source of infection transmission. However, most COVID-19 published studies are focused on the lower respiratory tract manifestation and sequels because of their life-threatening potentiality [7, 32].

Meanwhile, the literature on ENT manifestation during COVID-19 infection remains growing. Thus, there is value in studying smell dysfunction and other ENT manifestations of such novel virus and there is a need to recognize the defining smell dysfunction epidemiological and clinical characteristics in COVID-19 with more precision.

In the current review of literature, we tried to collect the data concerning the smell disorders associated with laboratory-confirmed COVID-19 cases in only the peerreviewed and published papers to provide an up-to-date delineation of the olfactory clinical characteristics and incidence in COVID-19 patients to help ENT and other physicians dealing with COVID-19 to understand and approach such cases and assist in data building up for this novel disease.

The results of the current study agree with previous reports [6-8] that fever (recounted in $57.4 \%$ of the included patients) and cough (reported in 69.8\%) are the principal symptoms of COVID-19 whereas gastrointestinal and ENT symptoms were less common, suggesting the difference in viral tropism as compared with influenza, SARS-CoV, and MERS-CoV $[4,21]$.

In the current study, the percentage of COVID-19 patients complaining of smell disorder was about 57\% with the fact that questionnaire as a tool in smell identification with poor sensitivity value $65.6 \%$. The most common ENT manifestation of COVID-19 in descending order were smell dysfunction (55.6\%), taste disorder (49.2\%), headache (42.8\%), nasal congestion and blockage $(26.3 \%)$, and sore throat (25.7\%). On the other hand, the most prevalent associated general symptoms in relation to smell and taste disorder in descending order were cough (69.8\%), fever (57.4\%), arthralgia/myalgia (44.5\%), asthenia/fatigue (36.7\%), loss of appetite (27.3\%), and dyspnea (22.2\%).

Degree of smell affection shows variability, anosmia accounts to about $58 \%$, while hyposmia about $41.6 \%$.

About $28.3 \%$ of affected patients complained of early smell affection as the only or first presentation with only $0.9 \%$ possibility of progression to severe or critical COVID-19. Late smell affection occurred 3-5 days after

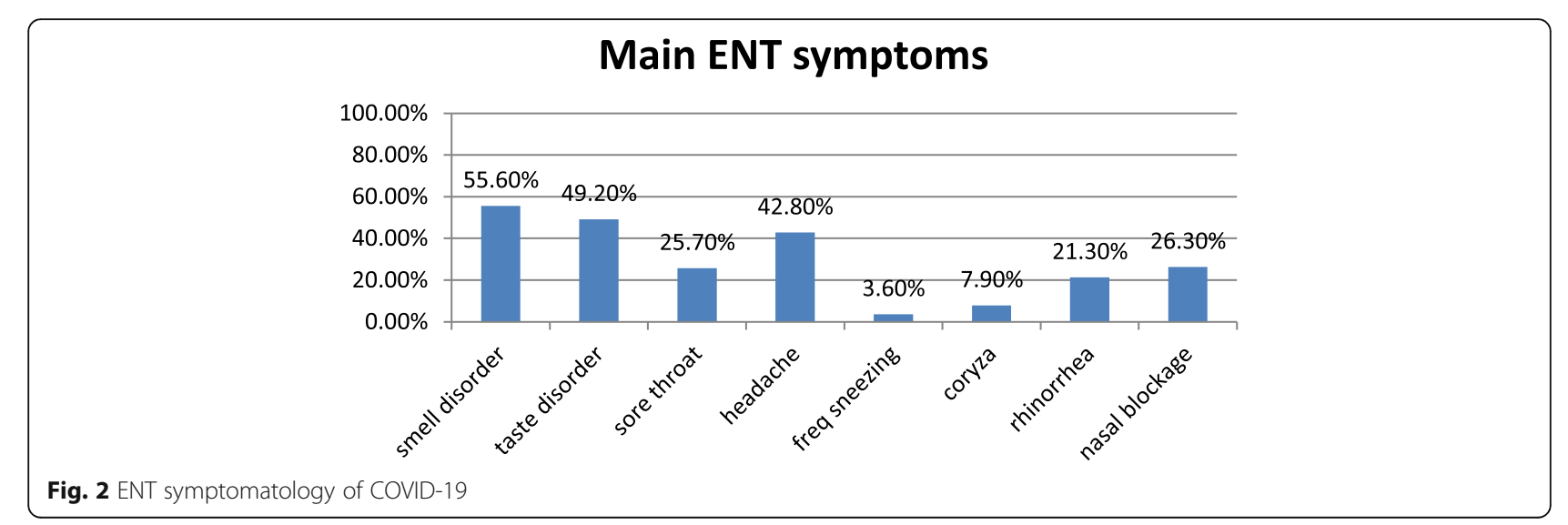




\section{General symptoms other than ENT manifestation}

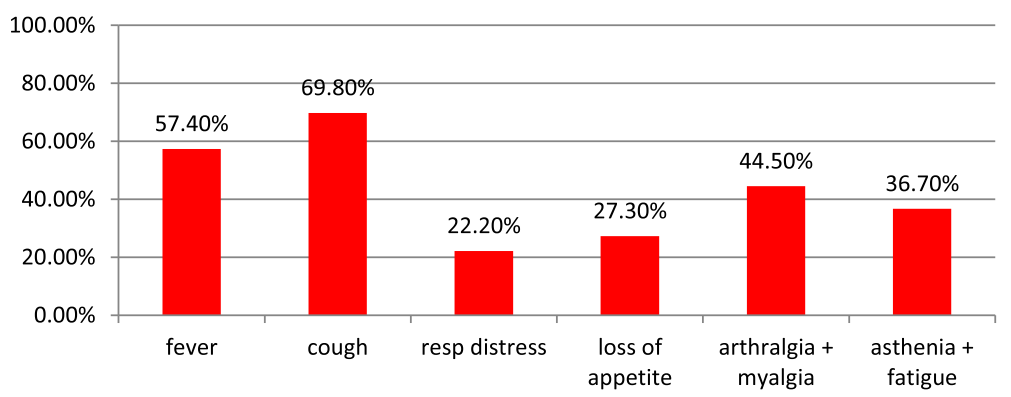

Fig. 3 General manifestations other than ENT symptoms in COVID-19

common acute respiratory tract infection in about $71.7 \%$.

Even though smell recovered in most cases (73.7\%) whether early recovery (within 2 weeks, 60.5\%) or later recovery (13.2\%), smell did not recover in more than one quarter of the patients (26.3\%). No specific regimen was associated with olfaction recovery. Vitamin, omega3 , and trace elements with nasal steroid were prescribed without evidence of superiority of certain medication. Olfaction recovery was reported even without medication. This must be discussed with the patients and the physicians and also there is a need to evaluate the used therapy in those patients and its effect on the smell recovery. Also the viral strain as director of the prognosis is another question.

As an overall view regarding the severity of COVID-19 and smell disorder, in less than $5 \%$ of the smell-affected patients, the COVID-19 was severe or critical. This may reflect no association between disease severity and smell affection, but smell disorder could be masked by both respiratory and critical manifestations in those severe and critical COVID-19 patients.

Post-viral anosmia is a widespread cause of adult smell dysfunction ( $40 \%$ of anosmia cases). Viruses that induce the common cold or upper respiratory tract infections are well known to lead to post-infectious smell loss. The previously defined corona viruses are assumed to account for $10-15 \%$ cases [33]. This novel viral infection seems to affect smell sensation over other viruses. Odds ratio describing likelihood of COVID-19 associating with smell disorder is over that of influenza virus by 4.5 folds [21]. Moreover, acute smell dysfunction is reported in COVID-19 infection over normal persons by 13.2 times (odds ratio of smell disorder in normal and COVID-19positive persons in two studies) with exclusion of obstructive olfactory disorder [17, 27].

Smell and taste dysfunctions were sparsely declared in the COVID-19 literature, and there is still a lack of peer- reviewed literature to support a causal association between COVID-19 and anosmia [6-8]. Olfactory neuritis is the most accepted theory of smell disorder but some studies emphasize on the presence of inflammatory change in olfactory cleft to be more than the changes affecting the olfactory neural pathway which is clearly detected by radiological studies like CT-MRI [16].

In peer-reviewed studies apart from case reports, smell dysfunction showed wide variation, with high records of 98.3\% [19] and 85.6\% [13] and low percentage of $5.1 \%$ [14] and $19.4 \%$ [10] respectively. However, they utilized a questionnaire focused on the psychological and social burden of the smell disorders, particularly with the COVID-19 pandemic scenario and the following social life restrictions, which might result in overestimation [13].

In the current review, smell affection was detected in $57 \%$ of included patients. Most COVID-19 studies particularly at the primary spread of the disease from December 2019 to March 2020 did not mention the smell affection particularly the early and primary reports, and most COVID-19 patients (66\%) reported a complete recovery of their chemosensitive functions during the disease course [23].

Zhang et al [34] recommend considering patients who complained of anosmia without runny nose or nasal obstruction COVID-19 suspicion and recommending starting testing or self-isolation for those patients.

\section{Limitations}

Because of the rapid serious health emergency of COVID-19, data collection and analysis are very difficult due to incomplete documentation lacking universal accurate description of the clinical manifestations without using a universal questionnaire for those patients. In addition, most COVID-19 studies missed asymptomatic or mild confirmed cases managed at home and there is very limited available ENT endoscopic or radiological 
data in COVID-19 published papers. All these mentioned limitations are features of the published researches on COVID-19 up till now and should be taken into consideration in future research. Moreover, most smell affection was evaluated via a questionnaire and patients were identified by the reported questionnaire submitted by themselves, which were not verified by the researchers. Besides, some essential information, such as gender and age, did not appear in some studies and previous history of smell disorders and nasal diseases and/ or nasal examination was not mostly mentioned. Many early COVID-19 studies did not ask about or test for smell disorders, and early questionnaire and/or checklist did not include smell disorders. Therefore, all included studies in the current review were published after March 2020. Chinese studies showed less smell mention that may be attributed to less doctors, patients, and community orientation about the condition or presence of different viral strains

Thus, we agree with El-Anwar et al [7] that a standard worldwide questionnaire for definite COVID-19 manifestations is required to make the COVID-19 data well defined, homogenous, and complete in order to deliver insights of diagnostic features of the common COVID19 manifestations.

Thus, otolaryngologists should be mindful of the symptom of anosmia in outpatients so as not to delay the diagnosis of COVID-19.

It is highly recommended to re-assess the recovered COVID-19 patients who become negative for late disease sequels including the smell examination and nose radiology since the late sequels of the COVID-19 infection after being negative need also to be assessed. Pathogenesis is not well understood, study of olfactory bulb size in those patients may point to the pathogenesis.

Otolaryngologists, physicians, patients, and the community should be aware of anosmia to avoid delaying the diagnosis of COVID-19 and thus contributing to an epidemic.

\section{Conclusions}

Olfactory manifestations for COVID-19 are common and should be added to suspected clinical criteria of COVID-19 particularly if nasal examination was nonsignificant. However, a standard universal questionnaire by well-defined COVID-19 manifestations is needed to make the COVID-19 data accurately defined, homogenous, and complete.

\section{Abbreviations}

SARS-CoV-2: Severe acute respiratory syndrome coronavirus 2; 2019nCoV: 2019 novel coronavirus; COVID-19: Coronavirus disease 2019; ARDS: Acute respiratory distress syndrome; UPSIT: University Of Pennsylvania Smell Identification Test; CCCRC: Connecticut Chemosensory Clinical Research Center orthonasal olfaction test

\section{Acknowledgements}

No one has to be acknowledged - every participant is included as author with no financial support.

\section{Authors' contributions}

ME, data collection, statistical analysis, manuscript writing and formatting, manuscript revision. SM, data collection - literature review, manuscript writing, manuscript formatting. AS, triggering the idea, data collection literature review, statistical analysis, manuscript writing and formatting, submission procedure. All authors have read and approved the manuscript.

\section{Funding}

No financial support

\section{Availability of data and materials}

All data generated or analysed during this study are included in this published article and its supplementary information files.

\section{Declarations}

Ethics approval and consent to participate

Not applicable-review article.

\section{Consent for publication}

Not applicable-review article.

\section{Competing interests}

No conflict of interest.

Received: 27 August 2020 Accepted: 5 April 2021

Published online: 01 May 2021

\section{References}

1. Huang C, Wang Y, Li X, Ren L, Zhao J, Hu Y, Zhang L, Fan G, Xu J, Gu X, Cheng Z, Yu T, Xia J, Wei Y, Wu W, Xie X, Yin W, Li H, Liu M, Xiao Y, Gao H, Guo L, Xie J, Wang G, Jiang R, Gao Z, Jin Q, Wang J, Cao B (2020) Clinical features of patients infected with 2019 novel coronavirus in Wuhan, China. Lancet. 395(10223):497-506. https://doi.org/10.1016/S0140-6736(20)30183-5

2. Zhu N, Zhang D, Wang W, Li X, Yang B, Song J, Zhao X, Huang B, Shi W, Lu R, Niu P, Zhan F, Ma X, Wang D, Xu W, Wu G, Gao GF, Tan W, China Novel Coronavirus Investigating and Research Team (2020) A novel coronavirus from patients with pneumonia in China, 2019. N Engl J Med. 382(8):727733. https://doi.org/10.1056/NEJMoa2001017

3. Drosten C, Günther S, Preiser W, van der Werf S, Brodt HR, Becker S, Rabenau H, Panning M, Kolesnikova L, Fouchier RAM, Berger A, Burguière AM, Cinatl J, Eickmann M, Escriou N, Grywna K, Kramme S, Manuquerra JC, Müller S, Rickerts V, Stürmer M, Vieth S, Klenk HD, Osterhaus ADME, Schmitz H, Doerr HW (2003) Identification of a novel coronavirus in patients with severe acute respiratory syndrome. N Engl J Med. 348(20):1967-1976. https://doi.org/10.1056/NEJMoa030747

4. de Wit E, van Doremalen N, Falzarano D, Munster VJ (2016) SARS and MERS: recent insights into emerging coronaviruses. Nat Rev Microbiol. 14(8):523534. https://doi.org/10.1038/nrmicro.2016.81

5. Rodriguez-Morales AJ, Cardona-Ospina JA, Gutiérrez-Ocampo E, VillamizarPeña R, Holguin-Rivera Y, Escalera-Antezana JP, Alvarado-Arnez LE, BonillaAldana DK, Franco-Paredes C, Henao-Martinez AF, Paniz-Mondolfi A, LagosGrisales GJ, Ramírez-Vallejo E, Suárez JA, Zambrano LI, Villamil-Gómez WE, Balbin-Ramon GJ, Rabaan AA, Harapan H, Dhama K, Nishiura H, Kataoka H, Ahmad T, Sah R, Latin American Network of Coronavirus Disease 2019COVID-19 Research (LANCOVID-19). Electronic address: https://www. lancovid.org (2020) Clinical, laboratory and imaging features of COVID-19: a systematic review and meta-analysis. Travel Med Infect Dis. 34:101623. https://doi.org/10.1016/j.tmaid.2020.101623

6. Meng X, Deng Y, Dai Z, Meng Z (2020) COVID-19 and anosmia: a review based on up-to-date knowledge. Am J Otolaryngol. 41(5):102581. https:// doi.org/10.1016/j.amjoto.2020.102581

7. El-Anwar MW, Elzayat S, Fouad YA (2020) ENT manifestation in COVID-19 patients. Auris Nasus Larynx 47(4):559-564. https://doi.org/10.1016/j.anl.2020. 06.003 
8. Lee Y, Min P, Lee S, Kim SW (2020) Prevalence and duration of acute loss of smell or taste in COVID-19 patients. J Korean Med Sci 35(18):e174. Published 2020 May 11. https://doi.org/10.3346/jkms.2020.35.e174

9. Giacomelli A, Pezzati L, Conti F, Bernacchia D, Siano M, Oreni L, Rusconi S, Gervasoni C, Ridolfo AL, Rizzardini G, Antinori S (2020) Self-reported olfactory and taste disorders in patients with severe acute respiratory coronavirus 2 infection: a cross-sectional study. Clin Infect Dis 71(15):889890. https://doi.org/10.1093/cid/ciaa330

10. Vaira LA, Salzano G, Deiana G, De Riu G (2020) Anosmia and ageusia: common findings in COVID-19 patients. Laryngoscope. 130(7):1787. https:// doi.org/10.1002/lary.28692

11. Villalba NL, Maouche Y, Ortiz MB, Sosa ZC, Chahbazian JB, Syrovatkova A, Pertoldi P, Andres E, Zulfiqar AA (2020) Anosmia and dysgeusia in the absence of other respiratory diseases: should COVID-19 infection be considered? Eur J Case Reports Internal Med 7(4):001641

12. Hjelmesæth J, Skaare D (2020) Loss of smell or taste as the only symptom of COVID-19. Tidsskr Nor Laegeforen. 3:140(7)

13. Lechien JR, Chiesa-Estomba CM, De Siati DR et al (2020) Olfactory and gustatory dysfunctions as a clinical presentation of mild-to-moderate forms of the coronavirus disease (COVID-19): a multicenter European study. Eur Arch Otorhinolaryngol. 277(8):2251-2261. https://doi.org/10.1007/s00405-02 0-05965-1

14. Mao L, Jin H, Wang M, Hu Y, Chen S, He Q, Chang J, Hong C, Zhou Y, Wang D, Miao X, Li Y, Hu B (2020) Neurologic manifestations of hospitalized patients with coronavirus disease 2019 in Wuhan, China. JAMA Neurol. 77(6):683-690. https://doi.org/10.1001/jamaneurol.2020.1127

15. Gilani S, Roditi R, Naraghi M (2020) COVID-19 and anosmia in Tehran, Iran. Med Hypotheses. 141:109757. https://doi.org/10.1016/j.mehy.2020.109757

16. Eliezer M, Hautefort C, Hamel AL, Verillaud B, Herman P, Houdart E, Eloit C (2020) Sudden and complete olfactory loss of function as a possible symptom of COVID-19. JAMA Otolaryngol Head Neck Surg. 146(7):674-675. https://doi.org/10.1001/jamaoto.2020.0832

17. Yan CH, Faraji F, Prajapati DP, Boone CE, DeConde AS (2020) Association of chemosensory dysfunction and COVID-19 in patients presenting with influenza-like symptoms. Int Forum Allergy Rhinol. 10(7):806-813. https://doi. org/10.1002/alr.22579

18. Klopfenstein T, Toko L, Royer PY, Lepiller Q, Gendrin V, Zayet S (2020) Features of anosmia in COVID-19. Med Mal Infect. 50(5):436-439. https://doi. org/10.1016/j.medmal.2020.04.006

19. Moein ST, Hashemian SM, Mansourafshar B, Khorram-Tousi A, Tabarsi $P$, Doty RL (2020) Smell dysfunction: a biomarker for COVID-19. Int Forum Allergy Rhinol. 10(8):944-950. https://doi.org/10.1002/alr.22587

20. Spinato G, Fabbris C, Polesel J, Cazzador D, Borsetto D, Hopkins C, BoscoloRizzo P (2020) Alterations in smell or taste in mildly symptomatic outpatients with SARS-CoV-2 infection. JAMA. 323(20):2089-2090. https:// doi.org/10.1001/jama.2020.6771

21. Beltrán-Corbellini Á, Chico-García JL, Martínez-Poles J, Rodríguez-Jorge F, Natera-Villalba E, Gómez-Corral J, Gómez-López A, Monreal E, Parra-Díaz P, Cortés-Cuevas JL, Galán JC, Fragola-Arnau C, Porta-Etessam J, Masjuan J, Alonso-Cánovas A (2020) Acute-onset smell and taste disorders in the context of COVID-19: a pilot multicentre polymerase chain reaction based case-control study. Eur J Neurol. 27(9):1738-1741. https://doi.org/10.1111/ ene.14273

22. Yan CH, Faraji F, Prajapati DP, Ostrander BT, DeConde AS (2020) Selfreported olfactory loss associates with outpatient clinical course in COVID19. Int Forum Allergy Rhinol 10(7):821-831. https://doi.org/10.1002/alr.22592

23. Kaye R, Chang CWD, Kazahaya K, Brereton J, Denneny JC 3rd. (2020) COVID19 anosmia reporting tool: initial findings. Otolaryngol Head Neck Surg. 163(1):132-134. https://doi.org/10.1177/0194599820922992

24. Ottaviano G, Carecchio M, Scarpa B, Marchese-Ragona R (2020) Olfactory and rhinological evaluations in SARS-CoV-2 patients complaining of olfactory loss. Rhinology. 58(4):400-401. https://doi.org/10.4193/Rhin20.136

25. Heidari F, Karimi E, Firouzifar M, Khamushian P, Ansari R, Ardehali MM, Heidari F (2020) Anosmia as a prominent symptom of COVID-19 infection. Rhinology. 58(3):302-303. https://doi.org/10.4193/Rhin20.140

26. Kim GU, Kim MJ, Ra SH, Lee J, Bae S, Jung J, Kim SH (2020) Clinica characteristics of asymptomatic and symptomatic patients with mild COVID19. Clin Microbiol Infect 26(7):948 e1-948.e3

27. Boscolo-Rizzo P, Borsetto D, Spinato G, Fabbris C, Menegaldo A, Gaudioso P, Nicolai P, Tirelli G, da Mosto MC, Rigoli R, Polesel J, Hopkins C (2020) New onset of loss of smell or taste in household contacts of home-isolated
SARS-CoV-2-positive subjects. Eur Arch Otorhinolaryngol. 277(9):2637-2640. https://doi.org/10.1007/s00405-020-06066-9

28. Luers JC, Rokohl AC, Loreck N, Wawer Matos PA, Augustin M, Dewald F, Klein F, Lehmann C, Heindl LM (2020) Olfactory and gustatory dysfunction in coronavirus disease 19 (COVID-19). Clin Infect Dis 71(16):2262-2264. https://doi.org/10.1093/cid/ciaa525

29. Vaira LA, Salzano G, Petrocelli M, Deiana G, Salzano FA, De Riu G (2020) Validation of a self-administered olfactory and gustatory test for the remotely evaluation of COVID-19 patients in home quarantine. Head Neck. 42(7):1570-1576. https://doi.org/10.1002/hed.26228

30. Vaira LA, Deiana G, Fois AG, Pirina P, Madeddu G, De Vito A, Babudieri S, Petrocelli M, Serra A, Bussu F, Ligas E (2020) Objective evaluation of anosmia and ageusia in COVID-19 patients: single-center experience on 72 cases. Head Neck. 42(6):1252-1258. https://doi.org/10.1002/hed.26204

31. Boscolo-Rizzo P, Borsetto D, Fabbris C, Spinato G, Frezza D, Menegaldo A, Mularoni F, Gaudioso P, Cazzador D, Marciani S, Frasconi S (2020 Jul) Evolution of altered sense of smell or taste in patients with mildly symptomatic COVID-19. JAMA Otolaryngol Head Neck Surg. 146(8):729-732. https://doi.org/10.1001/jamaoto.2020.1379

32. Hassan SA, Sheikh FN, Jamal S, Ezeh JK, Akhtar A (2020 Mar 21) Coronavirus (COVID-19): a review of clinical features, diagnosis, and treatment. Cureus. 12(3):e7355. https://doi.org/10.7759/cureus.7355

33. Dubé M, Le Coupanec A, Wong AHM, Rini JM, Desforges M, Talbot PJ (2018) Axonal transport enables neuron-to-neuron propagation of human coronavirus OC43. J Virol 92(17):e00404-e00418. Published 2018 Aug 16. https://doi.org/10.1128/JVI.00404-18

34. Zhang Q, Shan KS, Abdollahi S, Nace T (2020) Anosmia and ageusia as the only indicators of coronavirus disease 2019 (COVID-19). Cureus 12(5):e7918. Published 2020 May 1. https://doi.org/10.7759/cureus.7918

\section{Publisher's Note}

Springer Nature remains neutral with regard to jurisdictional claims in published maps and institutional affiliations.

\section{Submit your manuscript to a SpringerOpen ${ }^{\circ}$ journal and benefit from:}

- Convenient online submission

- Rigorous peer review

- Open access: articles freely available online

High visibility within the field

- Retaining the copyright to your article

Submit your next manuscript at $\boldsymbol{\nabla}$ springeropen.com 